\title{
Motivasi Perempuan Pelaku Pembunuhan (Studi Kasus pada Lembaga Pemasyarakatan Perempuan Kelas IIA Palembang)
}

\author{
Nabila \\ Politeknik Ilmu Pemasyarakatan, Indonesia \\ Jalan Raya Gandul No.4 Kec.Cinere, Kota Depok, Prov. Jawa Barat, Indonesia \\ Correspondence email: nabillaputri065@gmail.com
}

\begin{abstract}
Abstrak. Kehidupan narapidana merupakan suatu pola kegiatan atau aktivitas yang dilaksanakan bagi narapidana dan dikelompokkan di suatu tempat yang sifatnya tidak bebas (geraknya) sebagai bentuk untuk mempertanggungjawabkan segala perbuatannya agar dapat mengarahkannya kepada perbuatan yang benar menurut hukum dan agama dengan harapan agar mereka dapat bertobat dan menyesali segala perbuatannya ketika sudah bebas nanti. Sebutan bagi narapidana perempuan yang dibina didalam Lembaga Pemasyarakatan yaitu Warga Binaan Pemasyarakatan atau Klien Pemasyarakatan. Tindak pidana pembunuhan yang dilakukan oleh seorang perempuan memang menjadi hal yang sangat sulit dipercaya selama peradapan manusia di muka bumi ini. Kehidupan yang dijalani oleh seorang narapidana perempuan di Lembaga Pemasyarakatan sering kali membuat dirinya menghadapi berbagai masalah psikologis diantaranya yaitu kehilangan kepribadian diri akibat dari peraturan serta tata cara hidup yang sangat berbeda dengan kehidupan yang dijalani diluar Lembaga Pemasyarakatan. Penelitian ini bertujuan untuk mengetahui apa motivasi seorang perempuan melakukan suatu tindak pidana pembunuhan dan bagaimana menghadapi kondisi psikologis narapidana perempuan yang melakukan tindak pidana pembunuhan.
\end{abstract}

Kata Kunci: Motivasi; Narapidana Perempuan; Pembunuhan

\begin{abstract}
Prisoners' life is a pattern of activities or activities carried out for inmates and grouped in a place that is not free (movement) as a form of being responsible for all their actions in order to lead them to correct actions according to law and religion in the hope that they can repent and regret everything his actions when he is free later. The term for female prisoners who are fostered in a correctional facility is a prisoner or a correctional client. The crime of murder committed by a woman is indeed very hard to believe during human civilization on this earth. The life that is lived by a female prisoner in a correctional facility often causes her to face various psychological problems, including the loss of her personality as a result of rules and ways of life that are very different from life lived outside the Penitentiary. This study aims to determine what the motivation of a woman to commit a murder crime and how to deal with the psychological conditions of female prisoners who commit a murder crime.
\end{abstract}

Keywords: Motivation; Female Prisoners; Murder

\section{PENDAHULUAN}

Seiring dengan perkembangan zaman yang semakin meningkat, maka tingkat kejahatan dan kriminal di era globalisasi yang serba modern ini pun menunjukkan angka yang cukup tinggi. Terbukti dengan banyaknya berita yang ada di media elektronik maupun media cetak yang sering membicarakan mengenai tentang semakin meningkatnya tindak kejahatan yang dilakukan di Negara ini.

Tindak pidana pembunuhan merupakan salah satu contoh dari bentuk kejahatan yang paling keji. Karena pembunuhan merupakan suatu bentuk peristiwa menghilangkan nyawa seseorang baik itu dilakukan dengan sengaja ataupun dengan tidak sengaja sehingga menyebabkan kematian ${ }^{1}$. Sedangkan menurut Tim Penyusun Kamus Besar Bahasa Indonesia (2008), pembunuhan dapat diartikan dengan perbuatan yang menghilangkan nyawa orang lain. Pembunuhan ini merupakan masalah sosial yang membuat masyarakat terganggu karena angka kejadian dari peristiwa pembunuhan ini yang semakin hari semakin meningkat. ${ }^{2}$

Ketika mendengar Perempuan dikaitkan dengan kejahatan itu seperti sebuah kaitan yang ganjil, yang tidak mungkin dapat dilakukan oleh seorang perempuan, karena seperti yang kita ketahui bahwa perempuan mempunyai sifat yang lemah lembut serta jauh dari pemikiran melakukan sebuah kekerasan dan kejahatan. Jika dikaitkan dengan laki-laki banyak sekali perbedaan dengan perempuan namun bukan perbedaan yang rill, tetapi perbedaan yang di persepsikann. ${ }^{3}$ mengutip hasil penelitian yang dilakukan oleh Fodor \& Rothblum, dimana beberapa gangguan dapat dikelompokkan berdasarkan jenis kelamin, seperti yang diungkapkan Kartono dalam bukunya Psikologi Wanita ${ }^{4}$.

Tetapi faktanya, perempuan juga sangat berpotensi dalam hal melakukan sesuatu yang tidak dapat kita percayai

${ }^{1}$ Soehardi, A.S. (2006). Kamus Populer Kepolisian, Semarang: Wira Raharja Hal:208

2 Tim Penyusun Kamus Besar Bahasa Indonesia (2008). Kamus Besar Bahasa Indonesia. Jakarta: Pusat Bahasa Departemen Pendidikan Nasional

${ }^{3}$ Unger, Rhoda \& Mary Crawford, Women and Gender; A Feminist Psychology. (USA: Mc Graw Hill, 1992), hal:573

${ }^{4}$ Kartono, Kartini. (1992). Psikologi Wanita, Jilid I. Jakarta: Rajawali Pers. 
contohnya pembunuhan. Hal inilah yang kemudian memunculkan rasa bias didalam lingkungan masyarakat. Perempuan yang melakukan pembunuhan akan di stigma didalam masyarakat sebagai seorang pembunuh terlepas dari keadaan serta motif yang membuat perempuan tersebut melakukan suatu peristiwa pembunuhan. Karena bisa saja perempuan tersebut membela dirinya atau bahkan melindungi keluarganya contohnya melindungi anaknya, sehingga perempuan tersebut tanpa sengaja atau bahkan terpaksa membunuh. Apakah hal tersebut dapat dikatakan membunuh? Atau contoh lain ketika seseorang perempuan dalam hal ini tidak tau apa yang terjadi tetapi ia terlibat didalam sebuah tindak pidana pembunuhan apakah dapat dikatakan sebagai pembunuh? Berarti, dalam hal ini tidak ada pembatas yang pasti tentang definisi dari pembunuh itu sendiri dalam hukum dan didalam lingkungan masyarakat.

Motivasi merupakaan keadaan yang ada pada setiap individu yang dapat mendorongnya untuk dapat melakukan suatu aktivitas tertentu guna untuk pencapaian suatu tujuan tertentu. ${ }^{5}$. Berdasarkan definisi diatas bahwasannya karakteristik mengenai motivasi itu sendiri adalah suatu lingkungan yang berfungsi untuk mengaktifkan perilaku. Jika dilihat dari motivasi pelaku pembunuhan diatas, dapat dikatakan bahwa ketika seseorang perempuan melakukan suatu agresifitas seperti pembunuhan yang dilakukan akibat tertekan dengan suatu keadaan tertentu, maka secara mutlak terdapat suatu motivasi yang ada didalam diri pelaku pembunuhan tersebut. Disini peneliti ingin mencari tau apa saja yang memotivasi seorang perempuan dapat melakukan suatu tindak pidana kejahatan seperti pembunuhan.

Peneliti melihat bahwa tindak pidana pembunuhan yang dilakukan oleh seorang perempuan merupakan hal yang sulit untuk dipercaya selama peradapan manusia di muka bumi ini. tetapi tidak bisa kita pungkiri bahwa kenyataannya tindak pidana pembunuhan juga banyak dilakukan oleh seorang perempuan. Hal ini menjadi anomaly apabila dikaitkan dengan penilaian yang ada didalam masyarakat yang selalu beranggapan bahwa perempuan itu biasanya bersifat serta berperilaku lemah lembut, santun, dan berperan sebagai pendamai keadaan.

Dilihat dari permasalahan diatas, peneliti tertarik untuk melakukan penelitian mengenai Motivasi Perempuan Pelaku Pembunuhan (Studi di Lembaga Pemasyarakatan Kelas IIA Palembang). Dalam hal ini peneliti akan memahami lebih mendalam mengenai factor-faktor apa saja yang memotivasi diri seorang perempuan melakukan tindak pidana serta peneliti juga ingin mengetahui bagaimana kondisi psikologis dari seorang narapidana perempuan pelaku pembunuhan.

\section{METODE}

Metode yang digunakan yaitu penelitian yuridis - empiris, dengan pertimbangan bahwa titik tolak penelitian ini merupakan keadaan yang nyata dan faktual serta terdapat didalam masyarakat. Dalam penelitian ini menggunkan pendekatan yuridis - sosiologis, yaitu metode pendekatan yang mengkaji dan menganalisis permaslaahan dari aspek sosialnya. Tujuan dari penelitian ini yaitu untuk mencari data pada suatu fenomena unik serta dapat mendeskripsiikan fenomena itu dalam sudut pandang psikologi, oleh karna itu metode yang digunakan dalam penelitian ini yaitu metode kualitatif dengan pendekatan studi kasus.

Lokasi penelitian dilaksanakan di Lembaga Pemasyarakatan Perempuan Kelas IIA Palembang. Jenis data yaitu menggunakan data primer. Data primer merupakan data yang didapatkan langsung dari responden. Adapun data primer yang didapatkan disini yaitu motivasi narapidana perempuan kasus pembunuhan serta dampak psikologis narapidana perempuan kasus pembunuhan. Data sekunder yaitu didapatkan dari penelitian yang telah dilakukan sebelumnya. Data sekunder didapatkan dari dokumen -dokumen didalam Lembaga Pemasyarakatan Perempuan Kelas IIA Palembang, dan juga melihat dari hasil penelitian terdahulu, seperti skripsi, studi kepustakaan , doktrin, undangundang dan internet. Sumber data pada penelitian ini menggunakan data primer dan sekunder. Data primer diambil pada penelitian lapangan dengan pengumpulan data secara langsung dengan menggunakan metode wawancara dan pengamatan secara langsung. Sumber data sekunder menggunakan penelitian kepustakaan dengan mengumpulkan data dari Lembaga Pemasyarakatan Kelas IIA Palembang.

Subjek dipilih dengan menggunakan teknik purposive. Karakter subjek didalam penelitian ini yaitu : a) Narapidana kasus pembunuhan yang telah divonis hakim berupa hukuman penjara yang tengah menjalani masa pidananya didalam Lembaga Pemasyarakatan, b) Subjek merupakan seorang narapidana perempuan kasus pembunuhan, c) Tidak mempunyai gangguan kejiwaan, d) Memiliki persetujuan dari pihak Lembaga pemasyarakatan. Berdasarkan karakteristik tersebut, didapatkan dua orang narapidana kasus pembunuhan sebagi subjek penelitian. Metode pengambilan data didalam penelitian ini yaitu metode observasi, wawancara dan dokumen publik.

\section{HASIL DAN PEMBAHASAN}

Berdasarkan analisis hasil wawancara dengan subjek, observasii di lapangan (Lembaga Pemasyarakatan Perempuan Kelas IIA Palembang), hasil analisis psikologis, data wawancara dengan petugas Lapas serta data dokumentasi dan identifikasi di Lembaga Pemasyarakatan Perempuan Kelas IIA Palembang. Kasus yang diteliti merupakan kasus narapidana perempuan yang melakukan pembunuhan

\footnotetext{
${ }^{5}$ Djaali, Psikologi Pendidikan, (Jakarta: Bumi Aksara, 2011), hal:101
} 


\section{Subjek pertama $(\mathbf{R N})$}

Subjek merupakan individu yang terlahir pada keluarga yang sedikit memberikan perhatian terhadap subjek. Ibu subjek juga jarang sekali berbicara serta berinteraksi kepada subjek. Subjek sejak kecil tinggal pada lingkungan dengan keluarga yang sangat sederhana serta dengan kondisi perekonomian yang kurang berkecukupan. Karena pada saat peneliti melakukan penggalian data terhadap subjek. Subjek berkata ia hanya lulusan SMP dan tidak melanjutkan ke SMA. Setelah subjek lulus dari SMP, subjek dipaksa orang tua nya untuk menikah dengan laki-laki yang bahkan subjek sendiri tidak mengenalnya. Dan yang lebih mengejutkan lagi bahwa Laki-laki itu berumur 32 tahun dan subjek sendiri berumur 17 tahun. Selisih umur antara subjek dan suaminya inilah yang membuat hubungan keluarga mereka kurang harmonis .

Cinta subjek kepada suaminya yang tidak tulus dari hati ini lah karena disebabkan oleh perjodohan dari kedua orangtuanya membuat subjek merasa tidak nyaman dalam menjalani hari-harinya, hal tersebut menjadikan subjek memulai perselingkuhan dengan kekasih barunya. Dengan berjalan nya waktu, subjek pun semakin hari menjadi dekat dengan kekasih barunya. Kedekatannya seperti hubungan antara suami dan istri.

Dengan kondisi rumah tangga subjek dan suami nya yang tak kunjung harmonis Timbul lah rencana subjek dengan selingkuhannya yang ingin membunuh suaminya. Sebelum subjek melakukan pembunuhan terhadap suaminya, subjek dan selingkuhannya sudah merencanakan alur dan kronologi nya terlebih dahulu agar berjalan dengan lancar, subjek tidak lupa untuk menyewa orang dalam hal melakukan pembuunuhan terhadap suaminya. Termasuk alat-alat apa saja yang akan dipergunakan pada saat membunuh suaminya.

Namun tepat dihari yang sama dengan peristiwa tersebut, subjek dan selingkuhannya ditangkap oleh pihak kepolisian padahal sebelumnya subjek dan selingkuhannya tidak mengakui perbuatan yang telah mereka lakukan terhadap suami subjek tersebut.

\section{Subjek Kedua (NV)}

Subjek adalah seorang anak bungsu dari 5 bersaudara, subjek dulunya merupakan mahasiswa dari salah satu universitas di Jakarta. Subjek mempunyai pacar (KK) yang telah berpacaran selama 1 tahun 6 bulan. Kemudian pada semester 4 subjek hamil namun pacar subjek tidak mau bertanggung jawab dan pergi menghilang dari kehidupan subjek. Semenjak subjek ditinggal pergi oleh pacarnya yang tidak bertanggung jawab subjek mulai kecewa ditambah lagi pada masa kehamilan ke 9 bulan orang tua subjek mengusir subjek dari rumah tempat tinggal subjek sebelumnya. Subjek merasa bahwa dirinya tidak ada artinya lagi dimata kedua orang tuanya sendiri. Pada masa yang rumit ini saya selaku peneliti merasakan bahwa subjek ini perempuan yang cukup kuat dalam menghadapi masalah yang subjek alami ditambah lagi kondisi subjek yang sedang hamil 9 bulan subjek diusir ibu kandung nya sendiri dari rumah.

Setelah itu subjek berusaha mencari tempat tinggal sementara untuk subjek istirahat dan mempersiapkan persalinan nya yang tinggal menghitung hari. Hingga pada suatu hari subjek melahirkan anaknya. Subjek sendiri berusaha mencari pekerjaan demi untuk menghidupi anak nya yang masih bayi. Subjek tinggal di kos berdua dengan anak nya yang baru lahir. Disini saya melihat bahwa perjuangan serta kerja keras subjek yang begitu besar untuk menghidupi anak nya hingga berusia 5 tahun.

Pada suatu hari subjek merasa kesal atau sedang emosi dikarenakan subjek sudah 3 bulan diberhentikan dari tempat kerjanya. Subjek tidak bisa memenuhi kebutuhan ekonomi dari sang anak, sehingga membuat sang anak menjadi rewel. Pada saat itu subjek tidak bisa menahan emosi nya sehingga subjek melakukan hal yang tidak diinginkan yaitu subjek memasukkan kepala anak nya kedalam kantong kresek kemudian mendekapnya sampai kurang lebiih 15 menit setelah itu subjek memukul wajah anak nya dan ternyata pukulan subjek cukup keras hingga hidung sang anak patah. Pada saat itu subjek melihat anak nya sudah tidak bergerak lagii.

Kemudian subjek membawa anak nya ke rumah sakit, tidak lama kemudian sang anak sudah tidak bernyawa lagi. Subjek menyesali perbuatannya. Tanpa berpikir panjang secara spontan subjek mengakui perlakuan nya terhadap anaknya sampai anak nya tidak bernyawa lagi kepada dokternyang menangani anaknya. Kemudian dokter melaporkan perbuatan subjek kepada polisi. Pada saat itu juga subjek di vonis bersalah telah melakukan suatu tindak pidana pembunuhan serta penganiayaan terhadap anak nya sendiri. Dan Subjek dikenakan vonis 5 tahun penjara.

Pada saat peneliti mewawancarai subjek di Lembaga Pemasyarakatan Perempuan Kelas IIA Palembang subjek sendiri mengakui bahwa dia mempunyai sifat bipolar. Bipolar itu sendiri yaitu gangguan terhadap mental yang ditandai dengan adanya perubahan emosi yang drastis. Karena Seseorang yang mempunyai sifat bipolar ini dapat merasakan gejala mania (sangat senang) dan depresif (sangat terpuruk). Penyebab dari sifat bipolar ini sendiri belum dapat diketahui. Akan tetapi ada yang berpendapat bahwa sifat bipolar ini merupakan efek dari adanya gangguan senyawa alami yang dapat menjaga fungsi dari otak . 


\section{Faktor yang Memotivasi Perempuan Pelaku Pembunuhan}

Dari hasil penggalian data yang dilakukan bahwa kedua subjek mempunyai latar belakang permasalah yang berbeda ketika melakukan tindakan pembunuhan, dilihat dari latar belakang kedua subjek maka ada 2 faktor yang mempengaruhi nya yaitu:

1. Faktor eksternal yaitu hubungan antar keluarga yang tidak harmonis karena selalu menggunakan kekerasan didalam rumah tangga, cemburuan, seks bebas, pergaulan bebas, dunia malam, perselingkuhan serta pola asuh yang diterapka salah. Berbagai bentuk dari hubungan keluarga yang tidak harmonis itu menyebabkan potensi yang mengakibatkan terjadinya tindak pidana pembunuhan. Belum lagi konflik yang terjadi ini akibat dari pasangan yang memiliki perbedaan yang terdapat didalam sebuah hubungan yang sangat rentan yang akhirnya dapat menimbulkan konflik didalamnya. Akibatnya konflik tersebut dapat meluas dan bahkan susah di selesaikan sehingga pada akhirnya dengan cara mengakhirii hidup merupakan pilihan terakhir yang diambil dari sebuah permasalahan ketika terjadi didalam suatu hubungan.

Selanjutnya masalah ekonomi yang merupakan salah satu alasan yang sangat berpengaruh didalam suatu hubungan sehingga seseorang dapat terlibat pada kasus tindak pidana pembunuhan. Karena untuk mencukupi segala kebutuhannya bahkan seorang bersikap keji dengan melakukan suatu kejahatan seperti pembunuhan . Terkadang juga karena factor ekonomi seseorang tidak dapat mengontrol emosi nya sehingga terjadi sesuatu yang tidak diinginkan yang dapat mengakibatkan seseorang melakukan penganiayaan hingga pembunuhan.

2. Faktor internal yaitu kondisi psikologis dan kepribadian yang merupakan salah satu faktor penting yang mempengaruhi keikutsertaan subjek didalam kasus pembunuhaan. Demgan keadaan psikologiis subjek yang sedang mengalami trauma terutama apablia menjadi korban dari kekerasan yang dilakukan didalam rumah tangga, stress yang berkepanjangan, kesulitan dalam menahan amarah, dan tidak dapat menuntaskan masalah yang dihadapi. Tipe kepribadian seseorang yang seperti pendendam, mudah terhasut, mudah terbawa emosi dan tidak dapat menahan amarah serta tidak dapat mengendalikan diri dalam menghadapi segala permaslaahan yang ada didalam kehidupannya. Sehinga berdampak buruk dan menimbulkan kejadian yang tidak diinginkan apalagi jika sampai terjadi suatu pembunuhan yang dilakukan oleh subjek. Sifat seperti ini yang peneliti lihat dan tampak dominan yang ada pada diri kedua subjek diatas.

\section{Dampak Psikologi Perempuan Pelaku Pembunuhan.}

Melihat dari hasil wawancara yang dilakukan peneliti terhadap dua narapidana perempuan kasus tindak pidana pembunuhan, adapun dampak psikologiis narapidana ketika sedang menjalani sanksi pidananya didalam Lembaga Pemasyarakatan yaitu dapat berupa suatu derita antara lain yaitu:

1) Loos of personality, yaitu ketika narapidana menjalani masa pidananya didalam Lembaga Pemasyaraktaan narapidana akan kehilangan bentuk kepribadian dirinya serta identitas dirinya karena hal ini merupakan salah satu peraturan dan tata cara hidup di lembaga pemasyarakatan

2) Loos of security, selama narapidana sedang menjalani masa pidananya didalam Lembaga Pemasyarakatan, narapidana akan selalu berada didalam pengawasan petugas.

3) Loos of liberty, narapidana akan kehilangan hak kemerdekaannya. seperti kehilagan kemerdekaan untuk menyampaiakan pendapat didepan umum, membaca surat kabar

4) Loos of personal communication, dalam hal iini narapidana akan dibatasi untuk dapat berkomuikasi kepada siapapun termasuk keluarga dari narapidana

5) Loos of good and service, yaitu narapidana akan kehilangan pelayanan.

6) Loos of heterosexual, selama narapidana menjalani masa pidananya akan ditempatkan didalam blok sesuai dengan jenis kelaminnya

7) Loos of prestige, yaitu narapidana akan kehilangan harga dirinya

8) Loos of belief, merupakan dampak dari hilangnya kemerdekaan yang dialami oleh narapidana yang mengakibatkan narapidana kehilangan rasa percaya diri, ketidaknyamanan didalam Lembaga pemasyarakatan dan kurangnya dalam bertindak untuk melakukan sesuatu

9) Loos of creativity, ketika narapidana menjalani masa pidananya, kreatifitas, ide, gagasan serta impian dan citacitanya juga terampas

Dampak dari Psikologiis narapidana yang ada diatas sering kali dialami oleh narapidana di awal masa pidana penjara, hal ini disebabkan karena narapidana masih membutuhkan banyak waktu untuk proses penyesuaian diri terhadap lingkungan yang baru serta peraturan dan tata tertib yang telah ditentukan di dalam Lembaga Pemasyarakatan Perempuan Kelas IIA Palembang. Setelah beberapa bulan menjalani masa pidana didalam lembaga pemasyarakatan, mengikuti dan melaksanakan program pembinaan serta pembimbingan narapidana mengakui 
bahwa mereka baru bisa menyesuaikan dirii terhadap lingkungan serta peraturan dan tata tertib yang telah ditetapkan di dalam Lembaga Pemasyarakatan Perempuan Kelas IIA Palembang.

\section{SIMPULAN}

Berdasarkan hasil pembahasan diatas, motivasi seorang narapidana perempuan melakukan suatu tindak pidana pembunuhan yaitu karena adanya suatu keadaan yang terdapat pada diri seseorang yang dapat mendorongnya untuk dapat melakukan suatu aktivitas tertentu guna untuk pencapaian suatu tujuan tertentu. Terdapat beberapa factor yang ditemukan yang merupakan penyebab dari terjadinya suatu tindak pidana pembunuhan yaitu faktor eksternal dan faktor internal. Faktor ekternal diantaranya, hubungan keluarga yang tidak harmonis yang selalu menggunakan kekerasan didalam keluarga, cemburuan bahkan penarapan pola asuh yang salah yang dilakukan didalam keluarga. Masalah ekonomi juga adalah salah satu faktor yang dapat menyebabkan seseorang terlibat didalam kasus tindak pidana pembunuhan. Faktor internal berupa kondisi psikologis serta tipe kepribadian yang merupakan salah satu factor penting yang dapat menimbulkan keterlibatan subjek pada kasus tindak pidana pembunuhan.

Dampak psikologis bagi narapidana yang melakukan tindak pidana pembunuhan yang banyak dialami narapidana pada awal masa pidana, dikarenakan narapidana sendiri membutuhkan waktu untuk melakukan penyesuaian diri terhadap lingkungan sekitar serta peraturan dan tata tertib yang telah ditetapkan di dalam Lembaga Pemasyarakatan Perempuan Kelas IIA Palembang

\section{DAFTAR PUSTAKA}

\section{Buku}

Djaali, Psikologi Pendidikan, Jakarta: Bumi Aksara. 2011

Kartono, Kartini. Psikologi Wanita, Jilid I. Jakarta: Rajawali Pers.1992

Soehardi, A.S. Kamus Populer Kepolisian, Semarang: Wira Raharja. 2006

Tim Penyusun Kamus Besar Bahasa Indonesia Kamus Besar Bahasa Indonesia. Jakarta: Pusat

Bahasa Departemen Pendidikan Nasional. 2008

Unger, dkk, Women and Gender; A Feminist Psychology. USA: Mc Graw Hill. 1992 